\title{
Металлорганические перовскиты для фотоники
}

\author{
О.И. Семенова \\ Институт физики полупроводников им. А.В. Ржанова СО РАН, \\ Новосибирск, 630090, пр. Ак. Лаврентьева, 13 \\ mел:+7 (383) 330-8591, факс:+7 (383) 333-2771, эл.nочта: oisem@isp.nsc.ru
}

DOI 10.34077/RCSP2019-67

Гибридные перовскиты - класс полупроводников с общей формулой $\mathrm{ABX}$, где $\mathrm{A}=\mathrm{CH}_{3} \mathrm{NH}_{3}($ метил аммоний); $\mathrm{B}=\mathrm{Pb}$ (свинец), $\mathrm{Sn}$ (олово); и $\mathrm{X}=\mathrm{Cl}($ хлор), $\mathrm{Br}($ бром), I(йод). На основе данного класса материалов за последние пять лет наблюдается значительный прогресс в области создания тонкопленочных солнечных элементов (СЭ) [1,2], светоизлучающих диодов [3], датчиков гамма - и рентгеновского излучения. Главным преимуществом металлорганических перовскитов является то, что для их синтеза используются распространенные достаточно дешевые исходные соединения и простые технологические приемы, исключающие энергоемкие стадии и вакуумные установки. Синтез пленок, основанный на осаждении из растворов при температурах вблизи комнатной, позволяет использование стеклянных и гибких пластиковых подложек и методы струйной печати. Также неоспоримым преимуществом является возможность изменения ширины запрещенной зоны полупроводника посредством количественного изменения соотношения разных анионов. Замена йода на бром и хлор дает изменение $\mathrm{E}_{\mathrm{g}}$ от 1,5 до 2,1 эВ.

$\mathrm{B}$ настоящее время наиболее изученным перовскитом является $\mathrm{CH}_{3} \mathrm{NH}_{3} \mathrm{PbI}_{3}$ - метиламмония трийодид свинца. При использования этого гибридного материала эффективность конверсии солнечной энергии в электрическую для лабораторных СЭ возросла с 3,5\% [1] в 2009году до 22\% в 2015 [2], т.е. почти сравнялась с КПД элементов на кремниевых подложках. Добиться такого КПД удалось благодаря уникальным свойствам $\mathrm{CH}_{3} \mathrm{NH}_{3} \mathrm{PbI}_{3}$, таким как оптимальная для СЭ ширина запрещенной зоны (1,5 эВ), высокое значение коэффициента поглощения солнечного спектра $\left(10^{5} \mathrm{~cm}\right.$ $\left.{ }^{1}\right)$, низкая энергия разложения экситонов (16 мэВ) и большая длина пробега носителей заряда (1 мкм в плёнках, 175 мкм в монокристаллах).

Другое интенсивно развивающееся применения перовскитов - светоизлучающие диоды (LED). B 2014 году в работе [4] сообщалось о первых светодиодах, которые показали квантовую эффективность $0,76 \%, 0,1 \%$ и $0,018 \%$ для ближнего инфракрасного, красного и зеленого излучения соответственно. Совсем недавно опубликованы сообщения о зеленых, красных и ближних инфракрасных LED с квантовой эффективностью 20,3\%, [5] 21,3\%, [6] и 20,7\%, [7] соответственно.

Некоторые компании уже работают над коммерческим внедрением СЭ из перовскитов. Австралийские и турецкие компании вместе активно подошли к коммерциализации перовскитовых солнечных батарей, и по прогнозам, уже к 2019 году они будут представлены на мировом рынке. Аналитики энергетической отрасли утверждают, что при стоимости в 50 центов за 1 кВт, солнечная энергия становится конкурентоспособной по отношению к ископаемому топливу. То есть переход на перовскитные СЭ в глобальном масштабе позволит снизить стоимость производства электроэнергии в разы.

\section{Лumepamypa}

[1] A. Kojima et al. // J. Am. Chem. Soc. 2009. V.131, P.6050-6051.

[2] W.S. Yang et al. // Science. 2015. V. 348, P.1234-1237.

[3] N.K. Kumawat et al.// Nanoscale. 2019 V. 11, P. 2109-2120.

[4] Z.-K. Tan et al.// Nat. Nanotechnol., 2014 V. 9, P. 687-692.

[5] K. Lin et al. // Nature, 2018, V.562, P.245 - 248.

[6] T. Chiba et al.// Nat. Photonics, 2018, V.12, P. 681 -687.

[7] Y. Cao et al. // Nature, 2018, V.562, P.249 - 253 